WHC-EP-0678

\title{
The Westinghouse Hanford Company Operational Environmental Monitoring Program CY-93
}

\author{
J. W. Schmidt
}

Date Published October 1993

Prepared for the U.S. Department of Energy Office of Environmental Restoration and Waste Management

(2) Westinghouse $\begin{aligned} & \text { P.O. Box } 1970 \\ & \text { Hanford Company } \\ & \text { Richland, Washington } 99352\end{aligned}$

Hanford Operations and Engineering Contractor for the

U.S. Department of Energy under Contract DE-AC06-87RL10930 


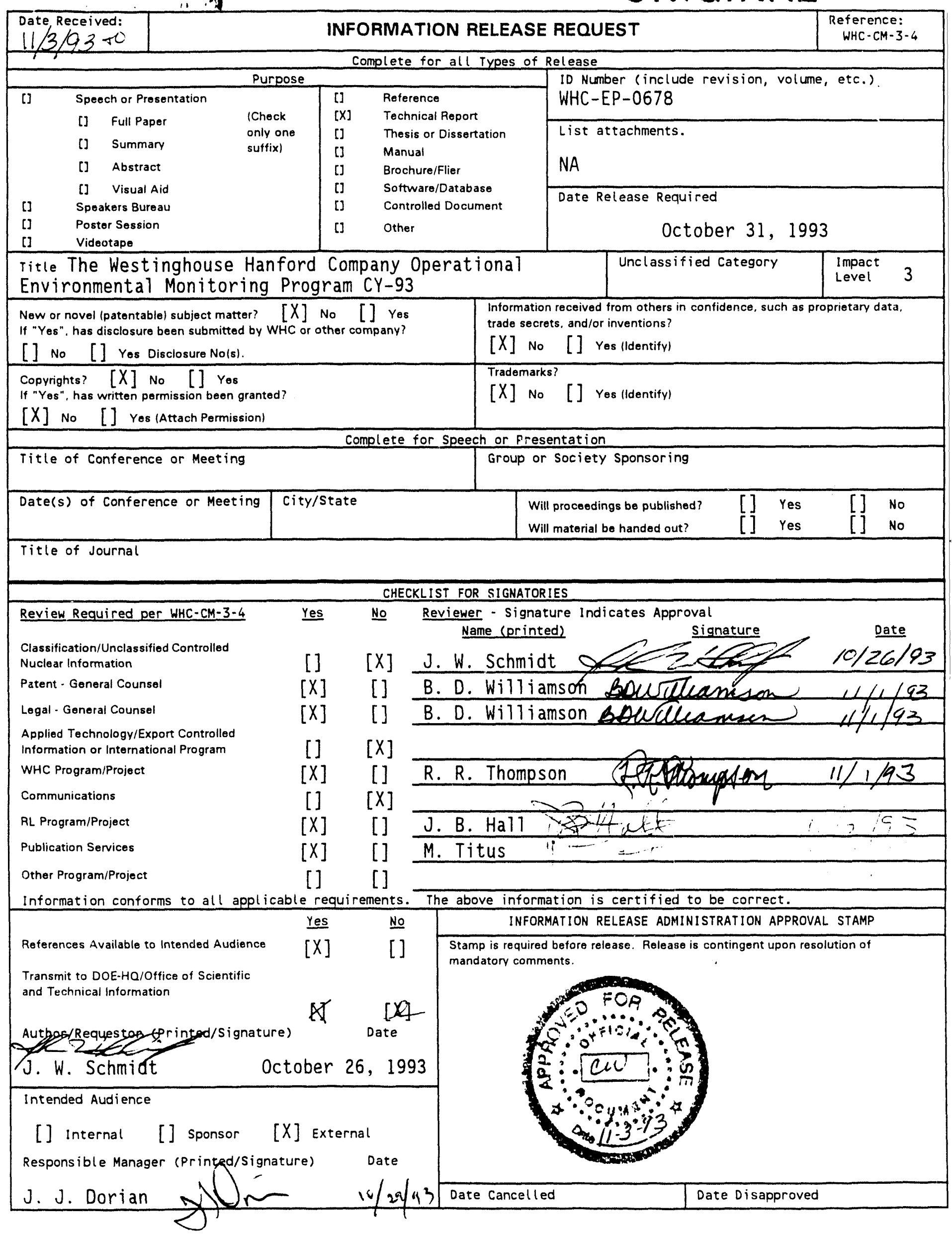




\section{CONTENTS}

1.0 INTRODUCTION . . . . . . . . . . . . . . . . . . . . . . . . . 1

1.1 Purpose of the Operational Environmental Monitoring Program . . 1

1.2 Background of Environmental/Effluent Monitoring at Hanford . . 2

2.0 ORGANIZATIONAL INTERFACES . . . . . . . . . . . . . . . . . . . . . 3

2.1 Operational Environmental Monitoring Program Interaction

Within Westinghouse Hanford Company . . . . . . . . . . . . . 3

2.2 Role of Environmental Restoration Management Contract . . . . . 5

3.0 DOCUMENT HIERARCHY . . . . . . . . . . . . . . . . . 5

4.0 SAMPLE MEDIA AND LOCATIONS . . . . . . . . . . . . . . . . . . . . . 7

4.1 Operational Environmental Monitoring Program Media and

Parameters........................ . 7

4.2 Sampling Locations.................... . . . . . 7

5.0 CURRENT PROGRAM STATUS (1993) . . . . . . . . . . . . . . . . . . . 8

5.1 Nonradiological Ambient Air Monitoring . . . . . . . . . . . . 9

5.2 Radiological Ambient Air Monitoring . . . . . . . . . . . . . 9

5.3 Soil ........................ . 10

5.4 Vegetation .. . . . . . . . . . . . . . . . . . 10

5.5 External Radiation Dose . . . . . . . . . . . . . . . 10

5.6 Surface Water . . . . . . . . . . . . . . . . . 10

5.7 River Seepages . . . . . . . . . . . . . . . . . . . . 11

5.8 Sediment and Aquatic Vegetation . . . . . . . . . . . . . . 11

5.9 Waste Site Surveys...................... 11

5.10 Animals . . . . . . . . . . . . . . . . . . . . . 11

APPENDIX:

A. PHOTOGRAPHS ...................... . . . . . . 
WHC-EP-0678

\section{LIST OF TABLES}

1 Operational Environmental Monitoring Program Interfaces . . . . . . 4

2 Document Hierarchy . . . . . . . . . . . . . . . . . . 6

3 Operational Environmental Monitoring Program Sampling Media, Frequency and Analytes ................... . 8 


\section{ACRONYMS AND ABBREVIATIONS}

$\begin{array}{ll}\text { AEC } & \text { U.S. Atomic Energy Commission } \\ \text { CERCLA } & \text { Comprehensive Environmental Response, Compensation, and } \\ & \text { Liability Act } \\ \text { CFR } & \text { Code of Federal Regulations } \\ \text { DOE } & \text { U.S. Department of Energy } \\ \text { EES } & \text { Environmental Engineering Studies } \\ \text { EPA } & \text { Environmental Protection Agency } \\ \text { ERA } & \text { Environmental Radiochemistry Analysis } \\ \text { ERMC } & \text { Environmental Restoration Management Contract } \\ \text { MOU } & \text { memorandum of understanding } \\ \text { NESHAP } & \text { National Emission Standards for Hazardous Air Pollutants } \\ \text { OEMP } & \text { Operational Environmental Monitoring Program } \\ \text { PNL } & \text { Pacific Northwest Laboratories } \\ \text { PU } & \text { Plutonium } \\ \text { RL } & \text { Richland Operations Office } \\ \text { RPR } & \text { Radiological Problem Reports } \\ \text { SCIR } & \text { Surveillance Compliance Inspection Reports } \\ \text { Sr } & \text { Strontium } \\ \text { TLD } & \text { thermoluminescent dosimeter } \\ \text { TPA } & \text { Tri-Party Agreement } \\ U & \text { Uranium } \\ \text { WAC } & \text { Washington Administrative Code } \\ \text { WDOH } & \text { Washington State Department of Health } \\ \text { WHC } & \text { Westinghouse Hanford Company }\end{array}$


WHC-EP-0678

This page intentionally left blank. 
WHC-EP-0678

\section{THE WESTINGHOUSE HANFORD COMPANY OPERATIONAL ENYIRONMENTAL MONITORING PROGRAM CY-93}

\subsection{INTRODUCTION}

\subsection{Purpose of the Operational Environmental Monitoring Program}

The Operational Environmental Monitoring Program (OEMP) provides facilityspecific environmental monitoring to protect the environment adjacent to facilities under the responsibility of Westinghouse Hanford Company (WHC) and assure compliance with WHC requirements and local, state, and federal environmental regulations.

The objectives of the OEMP are to evaluate the following:

- Compliance with U.S. Department of Energy (DOE), Environmental Protection Agency (EPA), Washington State Department of Ecology (Ecology), Washington State Department of Health (WDOH), and internal WHC environmental radiation protection requirements and guides

- Performance of radioactive waste confinement systems

- Trends of radioactive materials in the environment at and adjacent to nuclear facilities and waste disposal sites.

Specifically, the OEMP is developed to:

- Monitor all inactive, existing, and new low-level waste (LLW) disposal sites to assess both radiological and nonradiological hazards (DOE Order 5820.2A)

- Determine the effectiveness of effluent treatment and controls in reducing effluents and emissions (DOE/EH-0173T, Page 1-1, Paragraph 1) (DOE/EV/1830-T5)

- Detect and quantify unplanned releases (DOE/EH-0173T, Page 1-1, Paragraph 2) (40 Code of Federal Regulations [CFR] 302) (Washington Administrative Code [WAC] 17.3-303-145) (DOE 5000.3A) (DOE 5484.1)

- Monitor fugitive emissions and diffuse sources from contaminated areas for compliance with National Emission Standards for Hazardous Air Pollutants (NESHAP) (40 CFR 61), (DOE/EH-0173T, Pg. 3-4, 3.3.2), Toxic Air Emissions Inventory (40 CFR 265, Subparts AA and B13), State Operating Permit Program ( 40 CFR 70), and Source Registration (WAC 246-247).

- Monitor all surplus facilities prior to decontaminating or decommissioning (DOE Order 5820.2A).

- Monitor new and existing sites, processes, and facilities for potential impacts and releases (DOE Order 5484.1, and DOE/EH-0173T). 
- Monitor and assess radioactive contamination and potential exposure to employees and the public (DOE Orders 5400.1 and 5400.5).

The purpose and justification for the OEMP is contained in WHC-CM-7-4, Operational Environmental Monitoring, WHC-CM-7-5, Environmental Compliance.

The primary justification for the OEMP include the following:

- The OEMP provides a level of assurance to WHC that the effluent and contamination controls for the various facilities and waste sites are effective.

- The OEMP monitors a diversity of operations, activities, and programs managed by several different WHC organizations. Accordingly, the program direction and integration function performed by Environmental Engineering Studies (EES) is needed to assure program consistency, technical quality, and cost effectiveness.

- A secondary aspect of the OEMP is additional assurance beyond that provided by the Occupational Health and Safety Program that it is okay to work on site and for visitors to safely tour the site.

\subsection{Background of Environmental/Effluent Monitoring at Hanford}

1943 First environmental samples are collected at Hanford. Subsequent monitoring expands and improves the "program," but, there is no real coordination between general environment and operations areas.

1974 U.S. Atomic Energy Commission (AEC) manual chapters require AEC and its contractors to monitor and evaluate on-site discharges, liquid and airborne effluents and the environment in the vicinity of AEC Sites.

1978 An integrated operational environmental monitoring program in the

to 100 Areas is established in response to an Richland Operations office

1979 (RL) program review and operations directive. A grid system of monitoring is established in the 200 Areas which treats the 200 East and 200 West Areas as if they are each a "point source."

1979 O\&E Contractors begin annual "near-facility" environmental reporting.

to This involves up to five separate contractors. Coordination of data

1980 reporting is not encouraged and redundancies existed.

1987 In order to eliminate redundancy and to consolidate the site-wide and operations monitoring programs, a Memorandum of Understanding is developed which delineates the tasks of the Operations and Engineering and the Research and Development contractors. Major emphas is is placed on eliminating redundancy in sampling and monitoring, and in sharing information among the contractors.

1991 A few sample sites are collocated, to include the regulators, and expansion of information exchanges is accomplished. 
1993 Fine tuning of memorandum of understanding (MOU), sample and data sharing, technical exchanges to make certain that contractors are meeting all regulatory requirements, and eliminating redundant data acquisition, are ongoing activities.

\subsection{ORGRNIZATIONAL INTERFACES}

\subsection{Operational Environmental Monitoring Program Interaction Within Westinghouse Hanford Company}

In October 1992, WHC reorganized to better support the Hanford Site's evolving environmental mission. From the top down the President directs Restoration and Remediation (Restoration and Remediation) which consists, among others, of two departments/divisions, Regulatory Support and Environmental. The OEMP is a program administered by the EES Function which reports to the manager of Regulatory Support. The EES maintains the OEMP records which includes radiological data from the operations areas. Groundwater monitoring is a program administered by the Geosciences Function which reports to the manager of the Environmental Division.

The EES is responsible within WHC to plan, direct, and execute an effective, technically sound, near-facility operational environmental monitoring program for all media except groundwater, and to assure that the requirements of the program are implemented. This responsibility includes establishing the program basis and scope, developing sample and survey schedules, and assuring that schedules and procedures are followed by the performing organizations. EES serves as the primary WHC contact within and outside of the company in technical matters pertaining to near-facility operational environmental monitoring, and represents the company at meetings with environmental regulators regarding this program. Because the OEMP monitors a diversity of operations, activities, and programs managed by several different company organizations, the program direction and integration function performed by EES is important (Table 1). In addition, this integration function will likely become more important because both EPA and WDOH have significant interest in emission source registrations and the characterization of fugitive and diffuse emissions.

The EES utilizes data obtained by the OEMP to identify areas of noncompliance with WHC policy regarding loss of contamination control. The program utilizes Radiological Problem Reports (RPR) and Surveillance Compliance Inspection Reports (SCIR) as the formal mechanism of documenting instances of noncompliance. Formal tracking of noncompliances is accomplished once the report is placed in the Quality Environmental Safety Tracking system database. The OEMP staff are integral to the process of developing compliance schedules for the noncompliant organization which are then closely tracked to determine effectiveness. These reports solidify the oversight function of the OEMP and serve an important responsibility of formally identifying areas of concern regarding unacceptable environmental conditions. 
Table 1. Operational Environmental Monitoring Program Interfaces.

\begin{tabular}{|c|c|}
\hline Organization & $\begin{array}{l}\text { Operational Environmental Monitoring } \\
\text { Program Interface }\end{array}$ \\
\hline $\begin{array}{l}\text { Operations Support } \\
\text { Services }\end{array}$ & $\begin{array}{l}\text { Monitor and control of environmental contamination } \\
\text { in the } 600 \text { Areas, including roads, railroad tracks, } \\
\text { river shoreline and river island areas; maintenance } \\
\text { of operational environmental monitoring air } \\
\text { samplers; and land use development and site } \\
\text { selection planning. }\end{array}$ \\
\hline $\begin{array}{l}\text { Environmental } \\
\text { Restoration } \\
\text { Operations }\end{array}$ & $\begin{array}{l}\text { Surveillance to measure the effectiveness of the } \\
\text { inactive facility and waste site stabilization and } \\
\text { maintenance program in controlling and preventing } \\
\text { environirental contamination through biological and } \\
\text { physical transport mechanisms. }\end{array}$ \\
\hline $\begin{array}{l}\text { Environmental } \\
\text { Division }\end{array}$ & $\begin{array}{l}\text { Special operational environmental monitoring in } \\
\text { support of specific environmental cleanup } \\
\text { activities. So far this type of support has been } \\
\text { limited to Comprehensive Environmental Response } \\
\text { Compensation and Liability Act (CERCLA)/Tri-Party } \\
\text { Agreement (TPA) Expedited Response Activities. } \\
\text { Historical Operational Environmental Monitoring } \\
\text { information has also been provided to the } \\
\text { Environmental Restoration Engineering function } \\
\text { within the Environmental Division. }\end{array}$ \\
\hline $\begin{array}{l}\text { Tank Waste } \\
\text { Remediation System } \\
\text { Operations and } \\
\text { Engineering }\end{array}$ & $\begin{array}{l}\text { Monitor areas outside of Tank Farm facility fence } \\
\text { lines for activities that could effect the } \\
\text { immediate and offsite environment. Large areas of } \\
\text { outdoor surface contamination are associated with } \\
\text { the Tank Farm facilities. Tank Farm operations and } \\
\text { maintenance activities can and have resulted in } \\
\text { significant fugitive emissions and contamination } \\
\text { spreads. }\end{array}$ \\
\hline Facility Operations & $\begin{array}{l}\text { Provide near-facility environmental monitoring to } \\
\text { supplement and verify the adequacy of stack } \\
\text { monitoring data, and to monitor fugitive emissions } \\
\text { not discharged via specific vents and stacks. } \\
\text { Monitoring also helps ensure and verify the } \\
\text { adequacy of waste storage, and disposal practices } \\
\text { at facilities such as } N \text { Reactor, K Basins, } \\
\text { Plutonium-Uranium Extraction Plant, Plutonium } \\
\text { Finishing Plant, Fast Flux Test Facility, etc. }\end{array}$ \\
\hline $\begin{array}{l}\text { Solid Waste Disposal/ } \\
\text { Liquid Waste Disposal }\end{array}$ & $\begin{array}{l}\text { Monitor the adequacy of waste containment } \\
\text { associated with the solid and liquid waste disposal } \\
\text { facilities managed by this organization. These } \\
\text { facilities include burial grounds, waste storage } \\
\text { buildings and pads at the Central Waste complex, } \\
\text { cribs and trenches, and liquid effluent treatment } \\
\text { facilities. }\end{array}$ \\
\hline
\end{tabular}


Table 1. Operational Environmental Monitoring Program Interfaces.

\begin{tabular}{|l|l|}
\hline \multicolumn{1}{|c|}{ Organization } & \multicolumn{1}{|c|}{$\begin{array}{c}\text { Operational Environmental Monitoring } \\
\text { Program Interface }\end{array}$} \\
\hline $\begin{array}{l}\text { Projects and Site } \\
\text { Planning }\end{array}$ & $\begin{array}{l}\text { Provide data useful in determining location of } \\
\text { different projects, assist in determining the level } \\
\text { of pre-operational monitoring that would assure } \\
\text { compliance to the DOE Orders, provide expertise in } \\
\text { determining monitoring needs for a project. }\end{array}$ \\
\hline Health Physics & $\begin{array}{l}\text { Provide technical direction to Site Surveillance } \\
\text { Health Physics, develop sample and survey } \\
\text { schedules, and assure the sampl ing and survey } \\
\text { schedules are followed. Outdoor radiological } \\
\text { surveys, and surface contamination cleanup and } \\
\text { stabilization data are shared with the } \\
\text { Contamination Control Improvement Project. }\end{array}$ \\
\hline $\begin{array}{l}\text { Industrial Health and } \\
\text { Safety }\end{array}$ & $\begin{array}{l}\text { Recommend a program to characterize } \\
\text { diffuse/fugitive hazardous chemical emissions after } \\
\text { a review of existing reports, studies, data, etc. } \\
\text { already collected by IH\&S and other various WHC } \\
\text { programs. }\end{array}$ \\
\hline
\end{tabular}

\subsection{Role of Environmental Restoration Management Contract}

The WHC does not intend to turn over any established ambient monitoring stations of active operations to the ERMC. Temporary air monitoring stations have been established in the past to monitor specific Expedited Response Actions. This type of air monitoring will be turned over to the ERMC unless the ERMC decides to "Work Order" WHC's services. Direct radiological surveys of the inactive facilities will be turned over to the ERMC unless ERMC decides to "work order" WHC's services.

\subsection{DOCUMENT HIERARCHY}

A list which shows the governing document hierarchy pertaining to the OEMP is included in Table 2. The list includes the primary DOE Orders and regulations applicable to the program, and the Hanford Site and WHC implementation documentation. 
Table 2. Document Hierarchy.

\section{1}

General Environmental Protection Program, U.S. Department of Energy, Washington, D.C., 11-9-88

- Chapter III, Environmental Protection Program Plans

- Chapter IV, Environmental Monitoring Requirements

\section{5}

Radiation Protection of the Public and the Environment, U.S. Department of Energy, Washington, D.C., 1-07-93

- Chapter I, General, Paragraph 8, Effluent Monitoring and Environmental Surveillance

\section{$5820.2 A$}

Radioactive Waste Management,

U.S. Department of Energy, Washington, D.C., 09-26-88

\section{1}

Environmental Protection, Safety, and Health Protection Information Reporting Requirements,

U.S. Department of Energy, Washington, D.C., 10-17-90

$5000.3 A$

Occurrence Reporting and Processing of Operational Information, U.S. Department of Energy, Washington, D.C., 05-30-90

\section{DOE/EH-0173T}

Environmental Regulatory Guide for Radiological Effluent Monitoring and Environmental Surveillance

\section{CFR 61}

National Emission Standards for Hazardous Air Pollutants

40 CFR 70

State Operating Permit Programs

\section{CFR 265}

Interim Status Standards for Owners and Operators of Hazardous Waste Treatment, Storage, and Disposal Facilities

40 CFR 302

Designation, Reportable Quantities, and Notification

WHC-EP-0538-1

Operational Environmental Monitoring Program Quality Assurance Project Plan 
Table 2. Document Hierarchy.

WAC 173-303-145
Dangerous Waste Regulations (Spills and Discharges)
WHC-CM-7-4
Operational Environmental Monitoring and in DOE/RL 91-50,
Environmental Monitoring Plan.
DOE/RL-91-49
U.S. Department of Energy Richland Office Environmental Protection
Implementation Plan, November 9, 1991 through November 9, 1992
DOE/RL-91-50
Environmental Monitoring Plan U.S. Department of Energy Richland Office
WHC-CM-7-5
Environmental Compliance Manual

\subsection{SAMPLE MEDIA AND LOCATIONS}

\subsection{Operational Environmental Monitoring Program Media and Parameters}

As outlined in the RL Environmental Monitoring Plan (DOE/RL 91-50) dated November 1991, the OEMP samples the following media: external radiation dose, ambient air particulates, soil, surface water, sediment, and biota, at or near active and inactive facilities and waste sites. Parameters include, as appropriate, radionuclides, radiation exposure, hazardous constituents, pH, and water temperature. The OEMP is beginning to address nonradiological ambient air concerns raised by regulators (e.g., carbon tetrachloride near the $200 \mathrm{~W}$ ERA). The OEMP is examined at least annually to assure that requirements are met, appropriate effluents are monitored, and locations are optimum.

\subsection{Sampling Locations}

Samples are collected from known or suspected effluent pathways (e.g., downwind of potential releases, in liquid streams, or proximal to release points). To minimize duplication, WHC relies on existing sampling locations where Pacific Northwest Laboratories (PNL) has sample sites (e.g., 300 and 400 Area air samplers). Current sampling locations, frequency and analytes are shown in Table 3. Additional information regarding specific sampling locations can be found in WHC-CM-7-4. 
Table 3. Operational Environmental Monitoring Program Sampling Media, Frequency and Analytes.

\begin{tabular}{|lcl|}
\hline Sample Type & $\begin{array}{c}\text { Number } \\
\text { of Samples }\end{array}$ & \multicolumn{1}{c|}{ Collection Frequency } \\
\hline Air & 40 & Biwkly TA/TB Semi-annual Sr, Pu, U, Gamma \\
Soil & 157 & Annual Sr, Pu, U, Gamma \\
Vegetation & 95 & Annual Sr, Pu, U, Gamma \\
TLD & 107 & Quarterly Exposure \\
Survey Points & 182 & Annual Exposure Readings \\
$\begin{array}{l}\text { Liquid } \\
\text { Surface Disposal } \\
\text { (Pond and Ditch) }\end{array}$ & 11 & $\begin{array}{l}\text { Weekly pH, composited monthly for TA/TB, } \\
\text { Sr, Gamma. }\end{array}$ \\
$\begin{array}{l}\text { River Seepages } \\
\text { Sediment }\end{array}$ & 22 & Annual Sr, Gamma, ${ }^{3} \mathrm{H}$ \\
$\begin{array}{l}\text { Aquatic } \\
\text { Vegetation }\end{array}$ & 11 & Annual Sr, Pu, U, Gamma \\
\hline
\end{tabular}

NOTE: Animal samples are collected at or near facilities and/or waste sites when surveys indicate contamination, or the potential for contamination, and spread by biological vectors.

Also, routine surface contamination surveys are conducted near and on liquid waste disposal sites (e.g., cribs, trenches, drains, retention basin perimeters, pond perimeters, ditch banks), solid waste disposal sites (e.g., burial grounds, trenches), unplanned release sites, tank farm perimeters, stabilized waste disposal sites, roads, and firebreaks in the operations areas. There are 391 sites ( 100 in the 100 Areas, 273 in the 200/600 Areas, and 18 in the $300 / 400$ Areas) where radiological surveys were conducted.

\subsection{CURRENT PROGRAM STATUS (1993)}

This following section identifies and discusses the current status of monitoring (nonradiological ambient air, radiological ambient air, soil and vegetation, external radiation dose, surface water, sediment, and animals) conducted by the OEMP. 


\subsection{Nonradiological Ambient Air Monitoring}

At the present time, the EES does not conduct any environmental nonradiological air quality monitoring; however, the EES is carefully acquiring the capability so as to assure compliance with environmental regulations while minimizing budget impacts. This approach will actively address diffuse/fugitive emission concerns raised by environmental regulators.

Nonradiological ambient air quality measurements for parameters such as volatile organics or ammonia generally fall under the dual categories of effluent and contamination control as well as worker assurance. There appears to be a possibility of avoiding duplication of monitoring by having the various user groups share data from monitoring and sampling. Sometimes this monitoring is outside of the immediate work place; however, it is conducted to address regulators' concerns that effluent and contamination controls are adequate to demonstrate compliance with established standards.

Presently, EES' primary involvement is to characterize diffuse/fugitive hazardous chemical emissions. Better quantification of these sources is becoming necessary to address WDOH Source Registration, NESHAP, Toxic Air Emissions Inventory, and OEMP. The EES has committed to perform a review of existing reports, studies, data, etc., already collected by various WHC programs. The EES intends to recommend a technically justifiable and cost effective monitoring program based on this review.

\subsection{Radiological Ambient Air Monitoring}

Radiological ambient air quality measurements for parameters such as gross alpha and gross beta, as well as gamma energy analysis, uranium, plutonium and strontium on composited filters are performed at 40 stations per WHC-CM-7-4. With the exception of the three background stations, all of the air stations are located in close proximity to waste sites or facilities. In most instances a single air station or group of stations monitors several facilities and waste sites simultaneously. Biweekly gross alpha and gross beta analyses are performed at the 222-S $1 \mathrm{ab}$ as a screening for contamination prior to offsite shipment, as well as an early indication of "trouble" upwind of the sampler. All other analyses are conducted by International

Technologies Corporation Richland Laboratory.

In addition is the routine air particulate monitoring, the EES is conducting monitoring in the vicinity of Environmental Radiochemistry Analysis (ERA) (e.g., the 300 Area Process Trench ERA conducted in 1992). The EES is actively preparing for monitoring associated with the upcoming 618-11 transuranic removal ERA.

The EES staff are cognizant of the site's problem areas and activities and function as an oversight and coordinating presence. For example, occasionally, anomalous values for the measured parameters are observed (e.g., elevated gross beta downwind of S/SX/SY Tank Farms measured in October 1992 during air lance removal operations). These instances are coordinated with Facility Management and with Health Physics and Tank Farm Operations to determine cause(s) and appropriate corrective action. Also, PNL's SESP were queried to ascertain the extent of impacts. 
In addition, RL, PNL, and WHC are currently reviewing methodologies for determining radiation dose from diffuse sources as required in NESHAP (40 CFR 61, Subpart H).

\subsection{Soil}

Annual soil samples are collected from 157 sites located in close proximity to waste sites. Typically the monitoring results are used to identify trends of buildup of radionuclides. In most instances a single soil site or group of sites monitor several waste sites simultaneously. In response to the MOU between PNL and WHC, OEMP modified the soil sampling program to more directly assess the impacts of active waste sites.

\subsection{Vegetation}

Annual vegetation samples are collected from 95 sites located in close proximity to waste sites (Attachment 6 ). In most instances a single vegetation site or group of sites monitor several waste sites simultaneously. In response to the MOU between PNL and WHC, OEMP modified the vegetation sampling program to more directly assess the impacts of active waste sites.

\subsection{External Radiation Dose}

External radiation measurements are conducted using handheld instruments and thermoluminescent dosimeter (TLD) at 289 locations (182 annual survey points and 107 quarterly TLDs) in close proximity to facilities (e.g. Tank Farms, Evaporator) and waste sites. These measurements are used to assess the exposure rate or contamination spread near the facilities and waste sites to monitor the effectiveness of effluent and waste management controls (e.g., 1301 crib skyshine problem and pending corrective action). Data is trended and anomalous values are investigated to determine cause and appropriate corrective action.

\subsection{Surface Water}

Weekly samples are collected at 11 liquid surface disposal (pond and ditch) locations and analyzed for $\mathrm{pH}$, and composited monthly for total alpha, total beta, strontium-90 and gamma energy analysis. In addition, samples are collected quarterly for nitrates and tritium. The surface water samples serve as a check on liquid effluents and trends are maintained for comparison to normal operating conditions. Anomalous values trigger immediate review to determine cause and implement appropriate corrective action. 
WHC-EP-0678

\subsection{River Seepages}

Annual samples are collected from 22 river seepages along $N$ Springs and analyzed for strontium-90, gamma energy, and tritium. Sampling is conducted to trend hydrologic contaminant balance across the entire seepage zone. The OEMP seep samples constitute a check on effluents emanating from the liquid waste site.

\subsection{Sediment and Aquatic Vegetation}

Monitoring of 11 locations for sediment and 11 aquatic vegetation is performed annually at active ponds and ditches. Samples are analyzed for strontium, plutonium, Uranium, and gamma energy. Trending of data is performed to monitor the effectiveness of effluent and contamination control at the active ponds and ditches. This monitoring is performed primarily as a check on operations.

\subsection{Waste Site Surveys}

The survey of waste sites is conducted to comply with DOE Orders regarding the spread of contamination and is an extremely important aspect of the OEMP. These surveys help identify physical transport of radioactive materials as well as biological intrusion of waste sites and is one mechanism to demonstrate compliance to NESHAP ( 40 CFR 61 , Subpart $H$ ). Anomalous readings are investigated and documented in accordance with the RPR and SCIR system. Typically the monitoring results are used to identify trends of uptake of radionuclides. Special samples (e.g., soil, vegetation, animal feces, etc.) are taken where physical transport problems are identified. The purpose of these special samples is to assure effluent and waste management control at the waste sites.

\subsection{Animals}

Animal samples (usually small mammals, mammal or bird feces, birds, or bird nests) are collected at or near facilities and/or waste sites when surveys indicate contamination, or the potential for contamination, and spread by biological vectors. If surveys of any of the above media indicate the presence of contamination, further isotope specific characterization is performed to establish the source of the contamination. When contamination is identified investigations are conducted and documented in accordance with the RPR and SCIR system. 
WHC-EP-0678

This page intentionally left blank. 
WHC-EP-0678

APPENDIX A

PHOTOGRAPHS

A- $i$ 
WHC-EP-0678

This page intentionally left blank. 


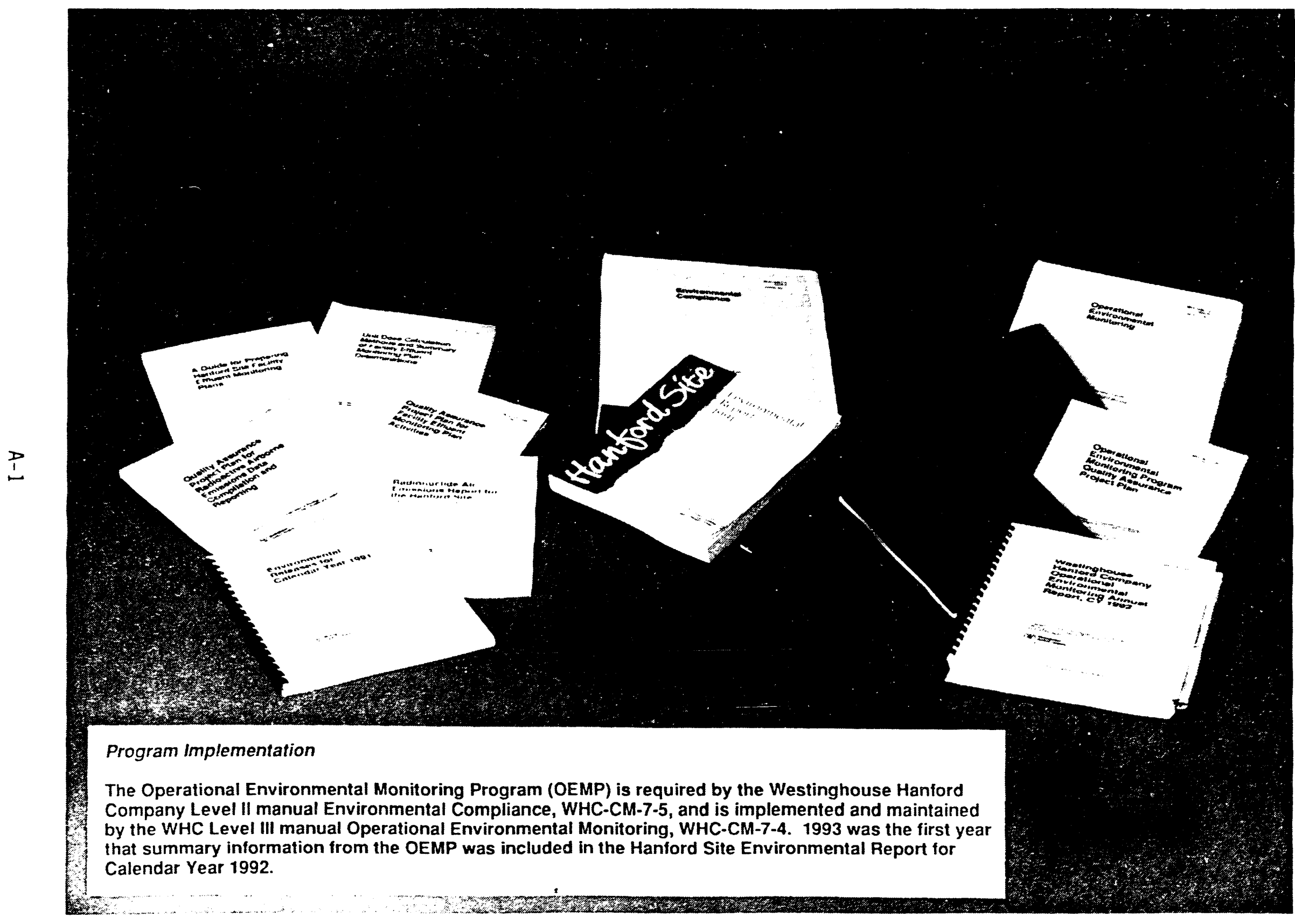




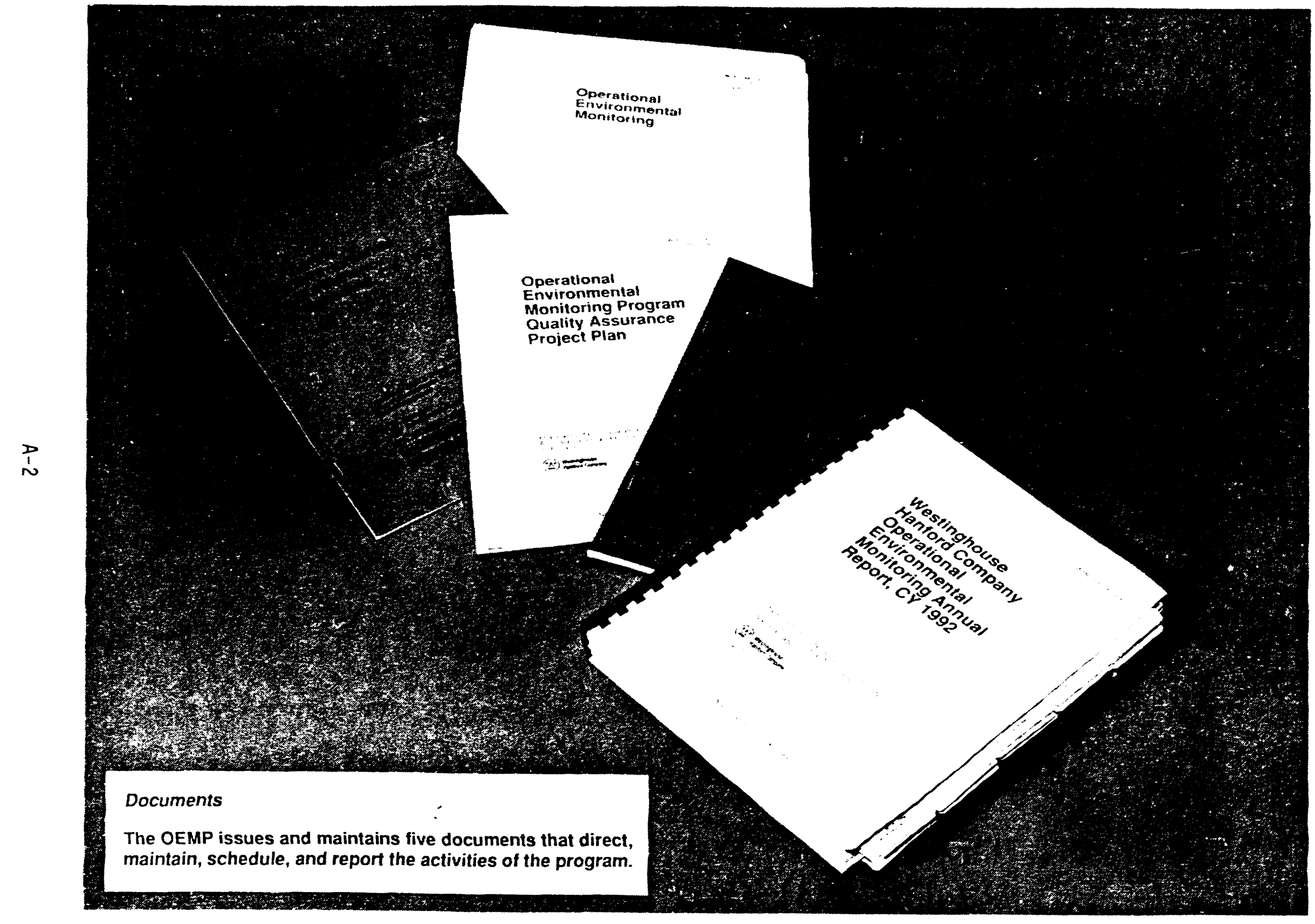




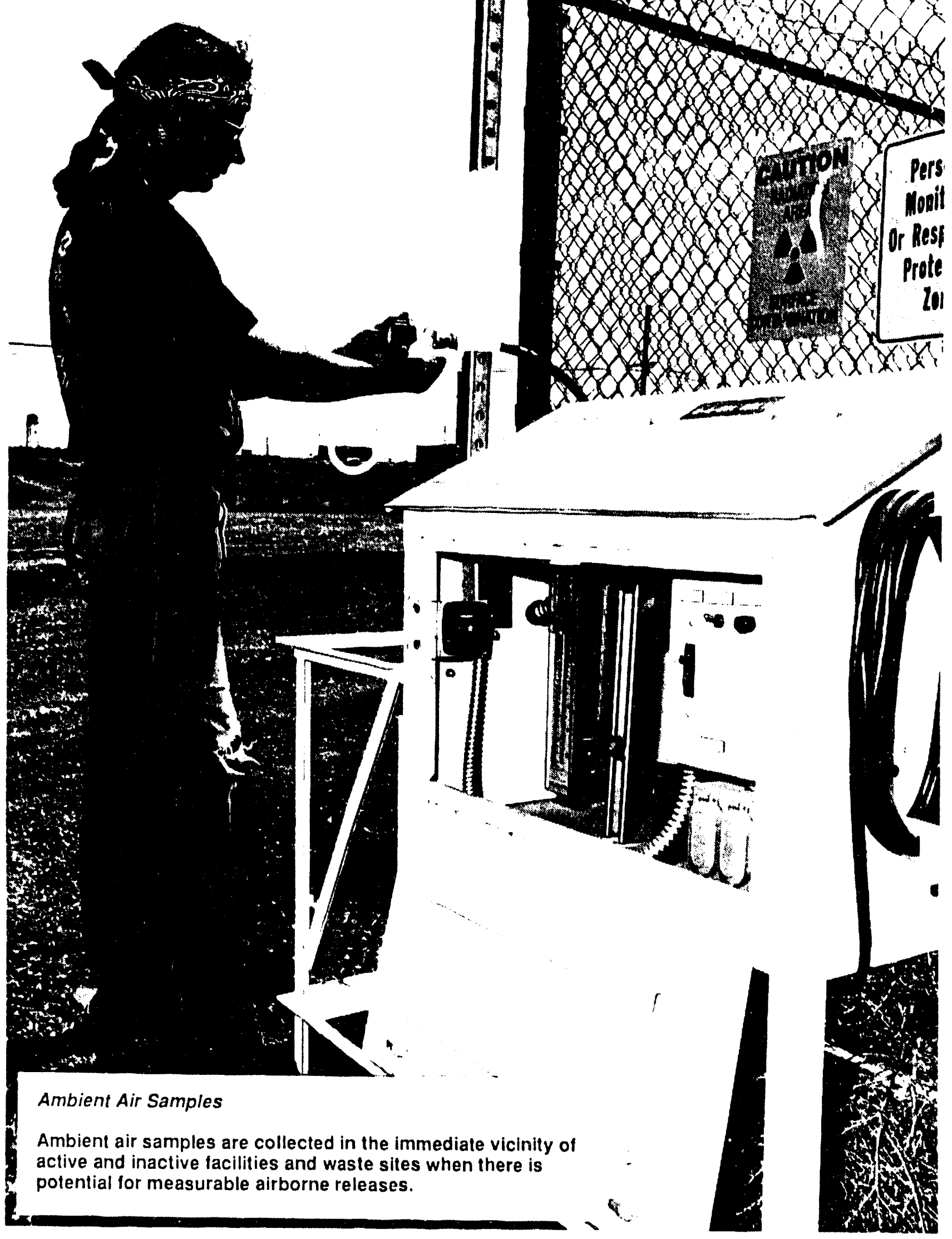




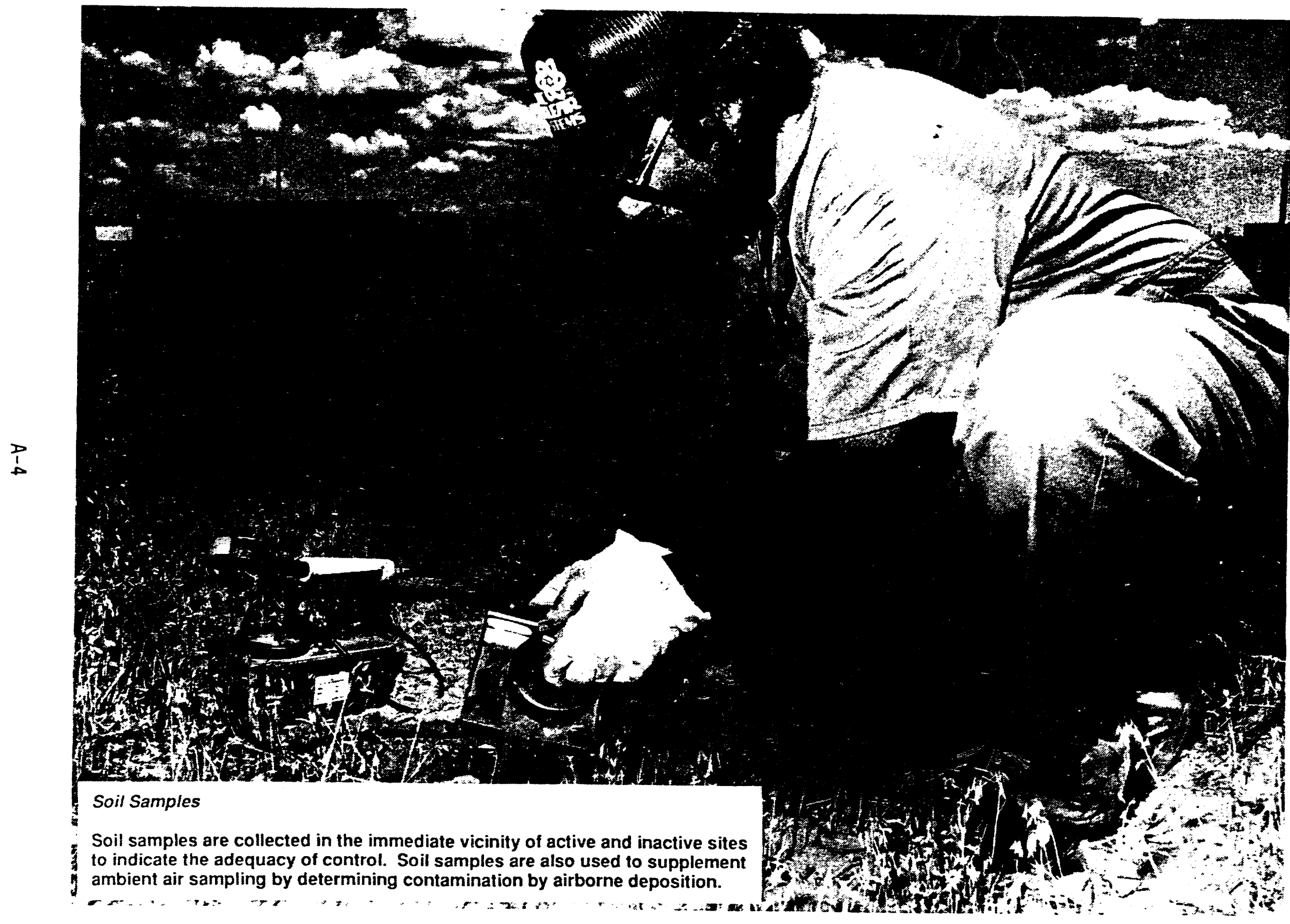




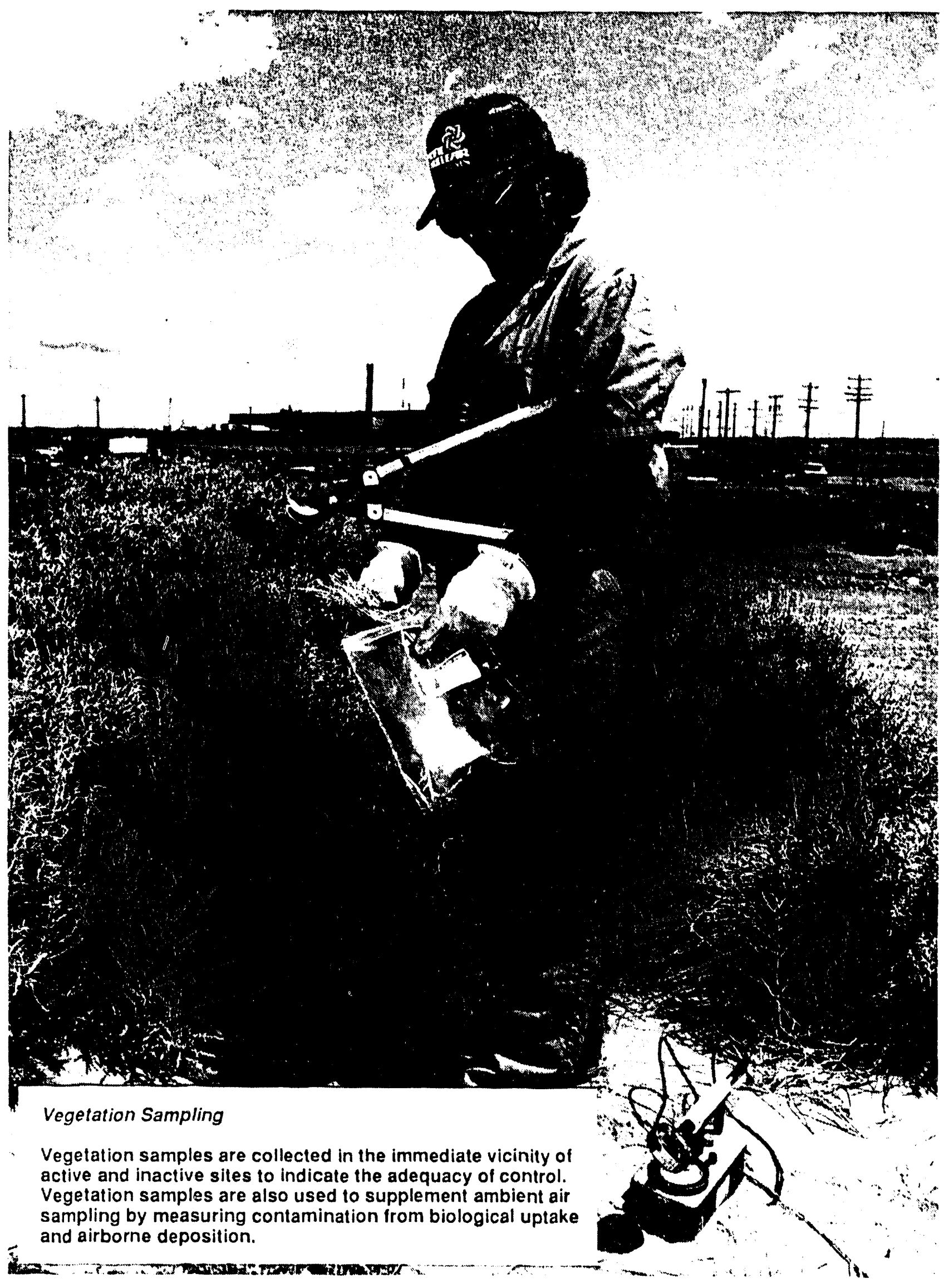




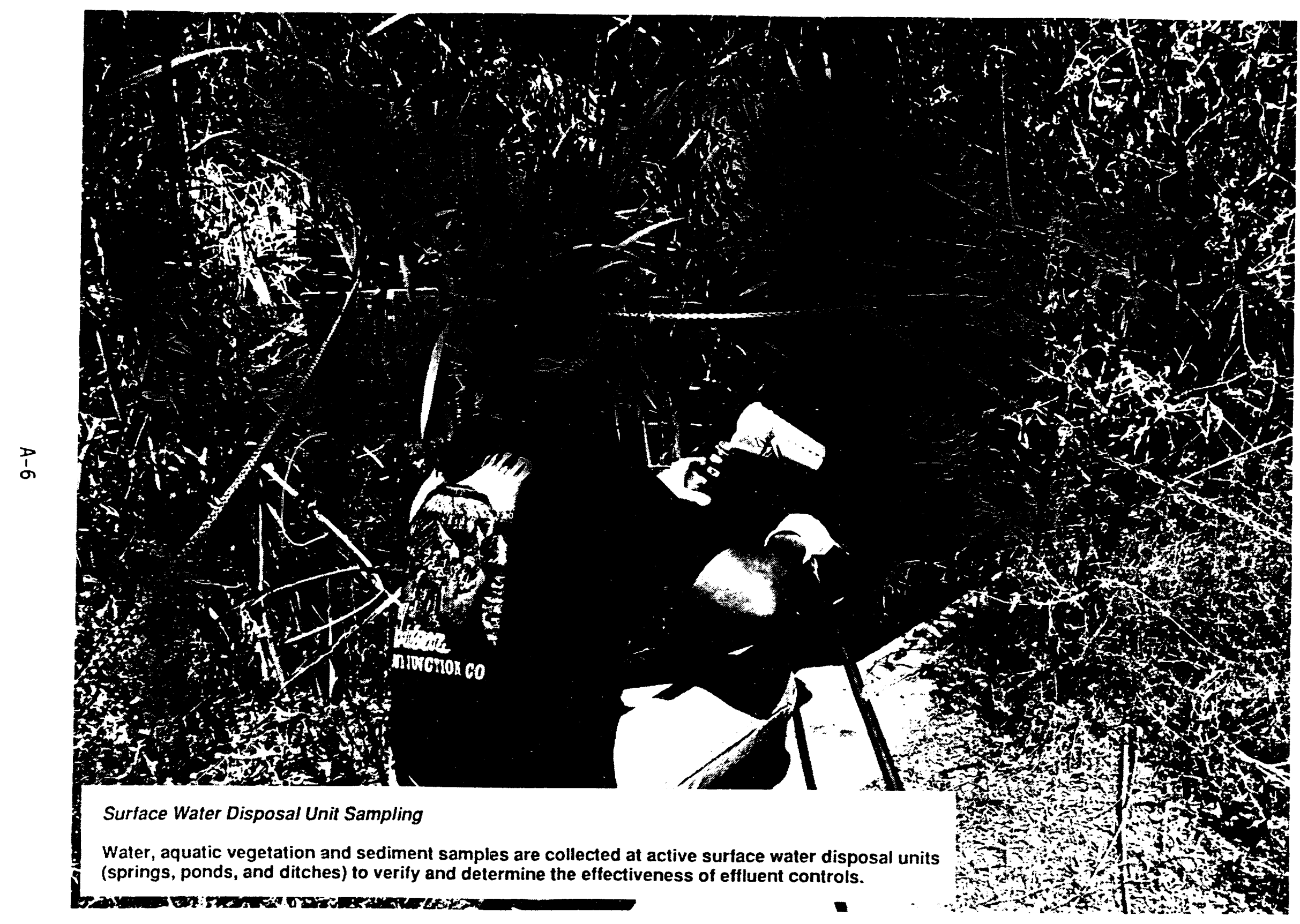




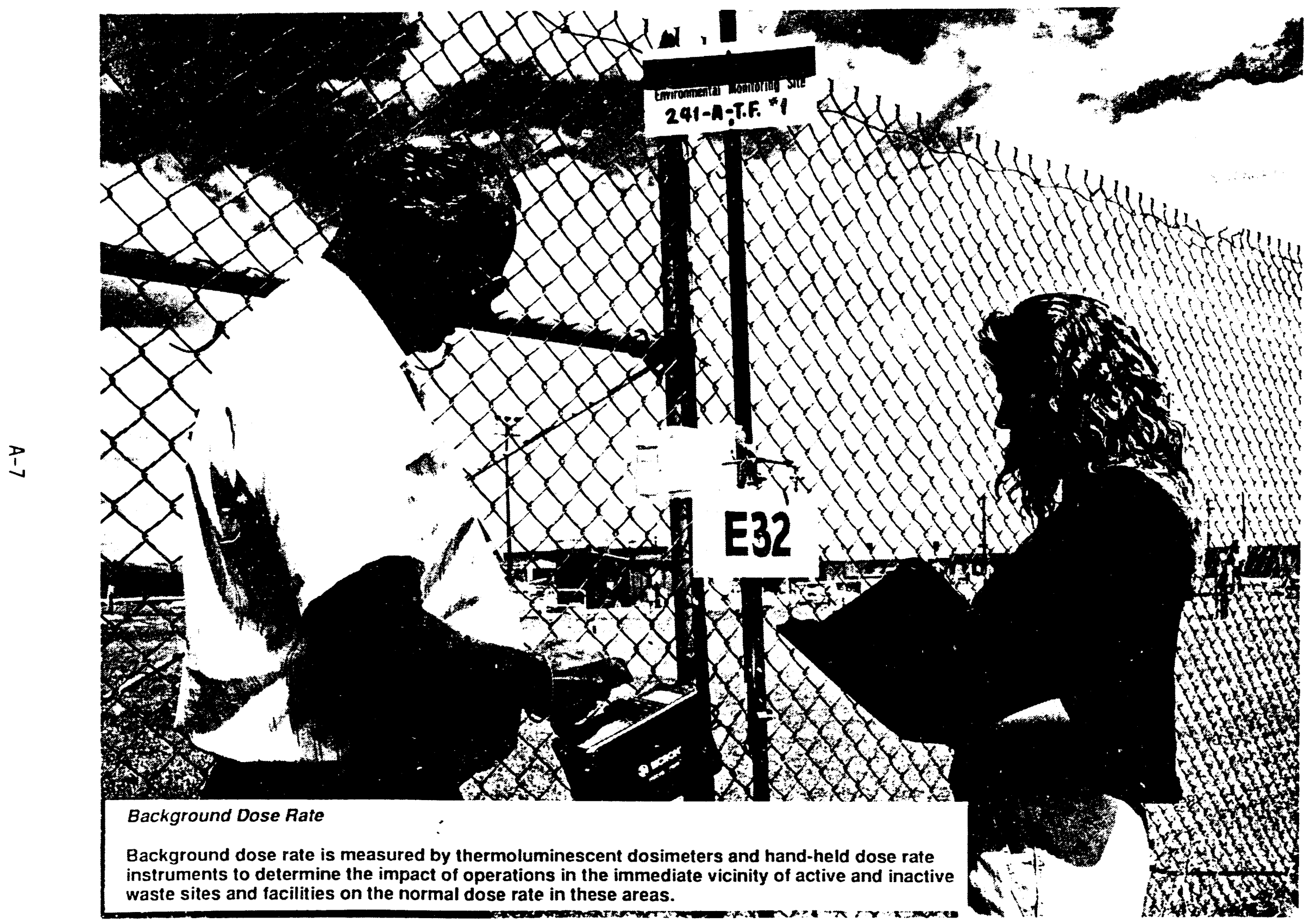




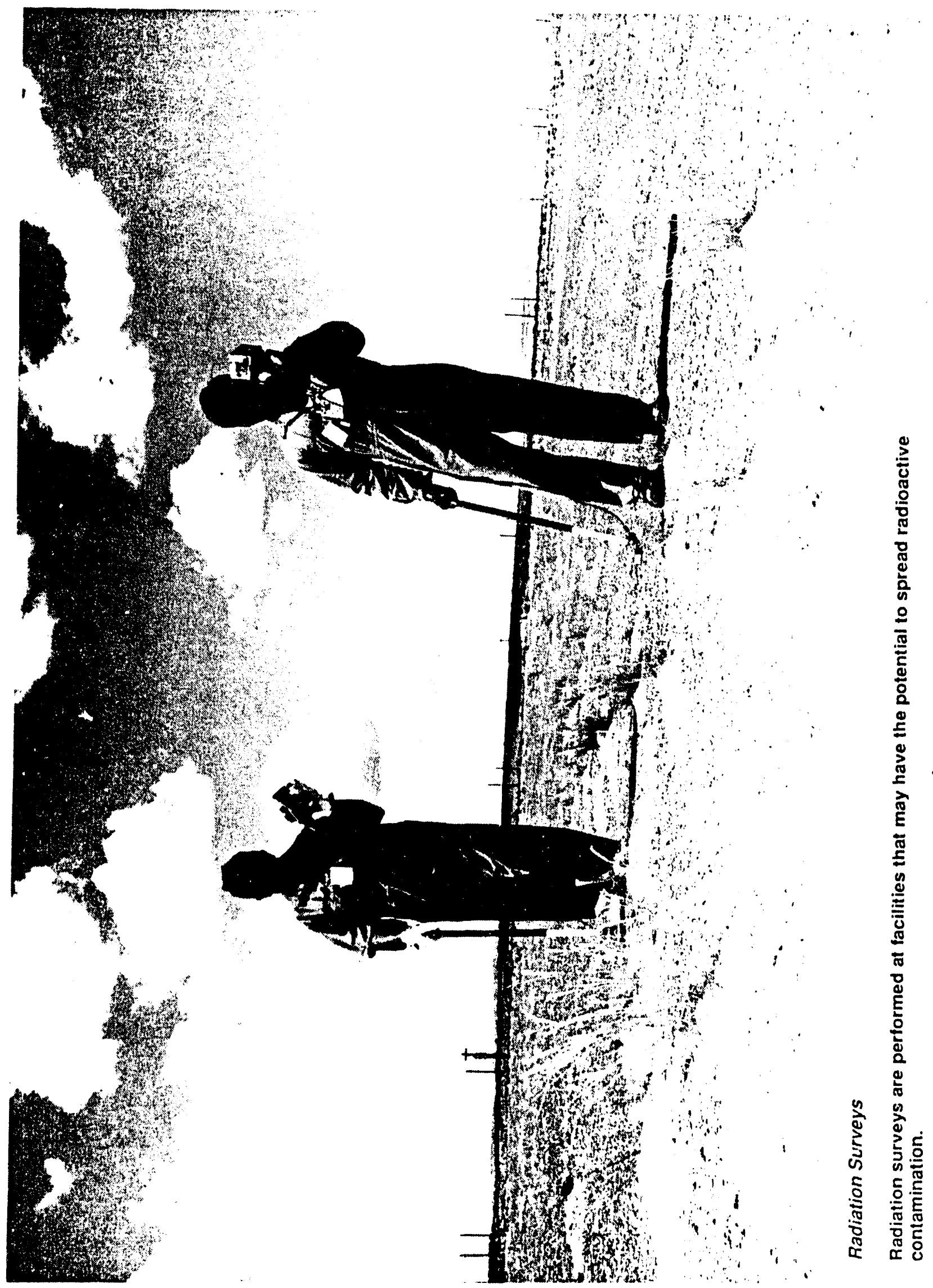



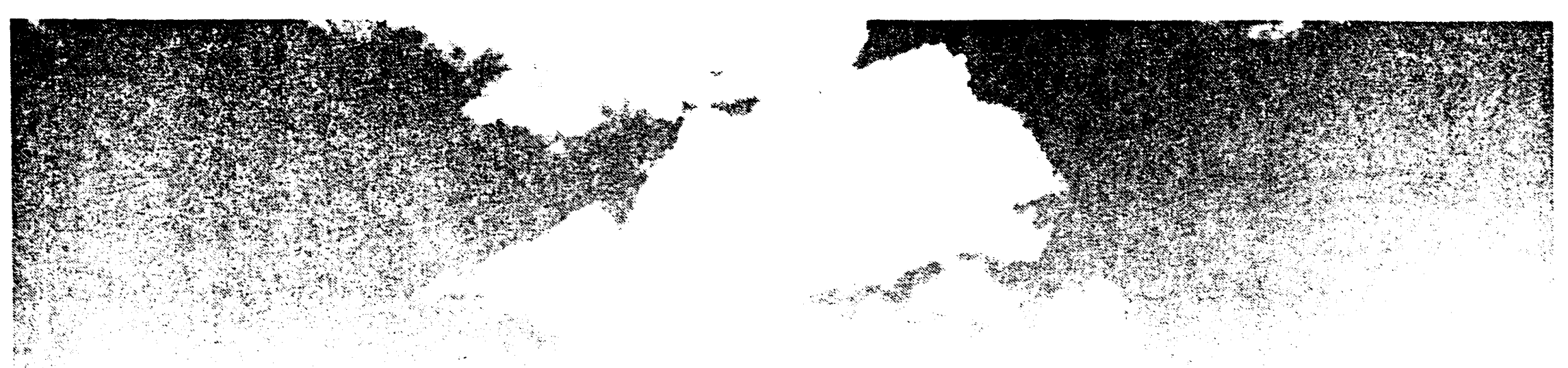

?

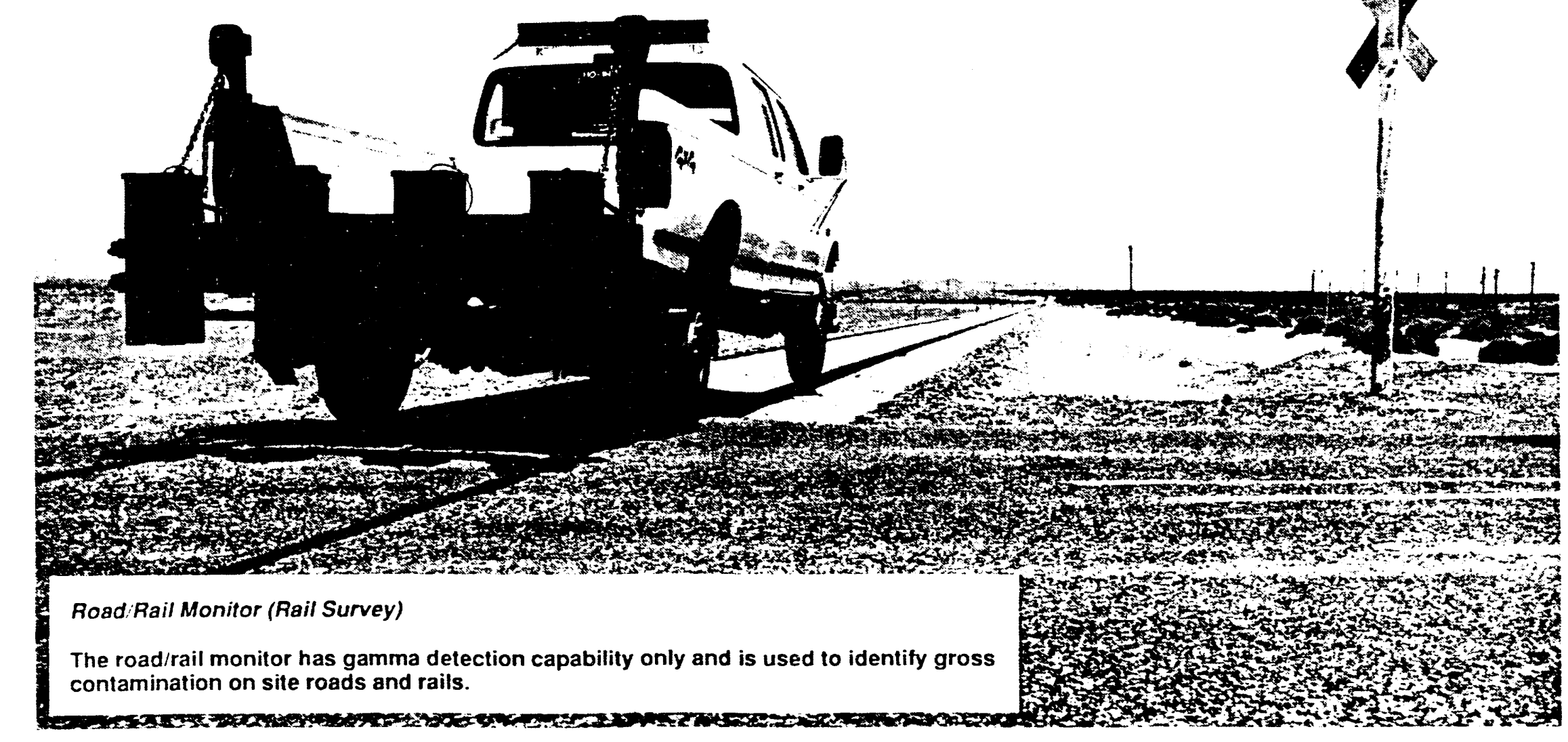




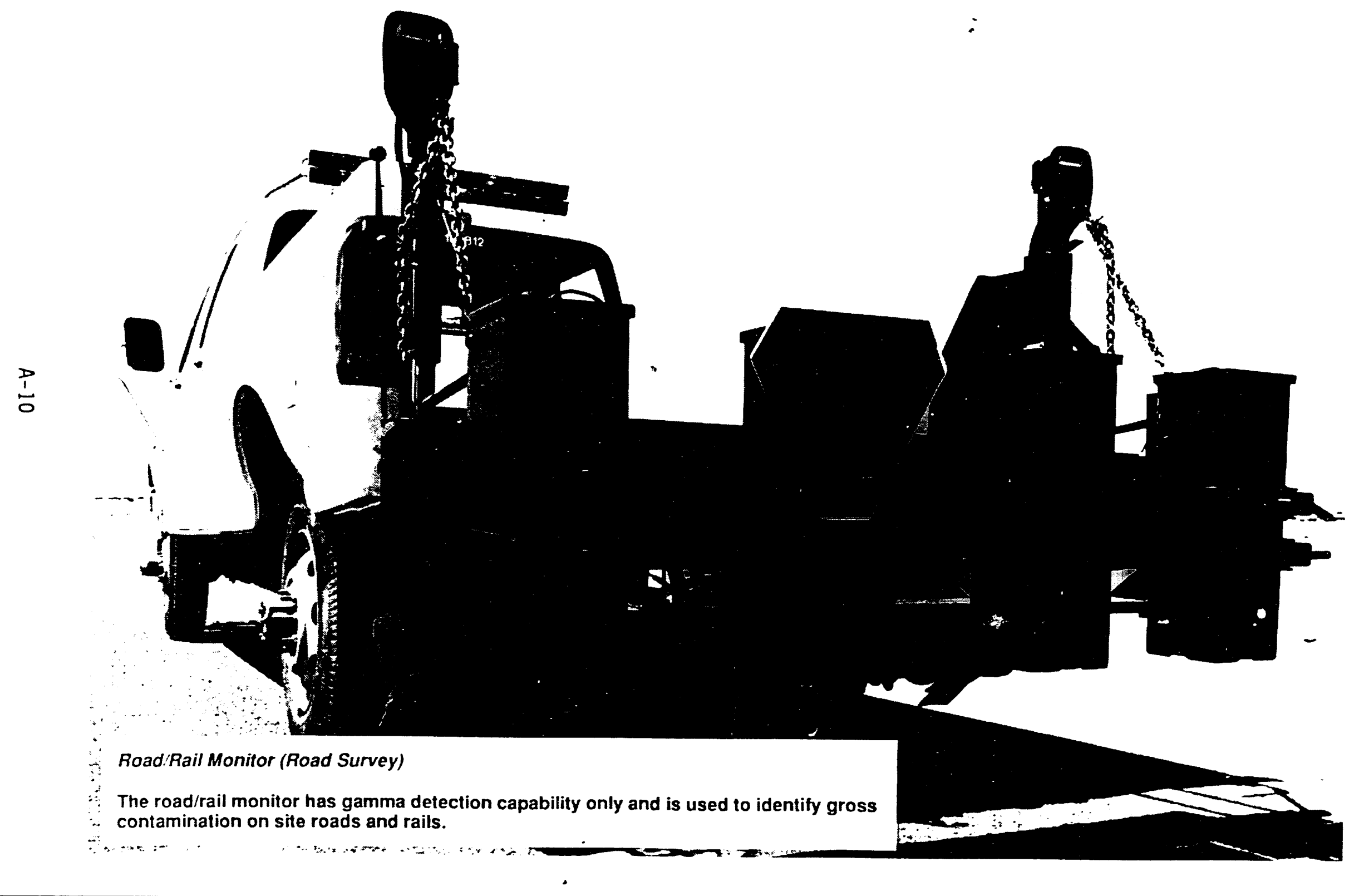




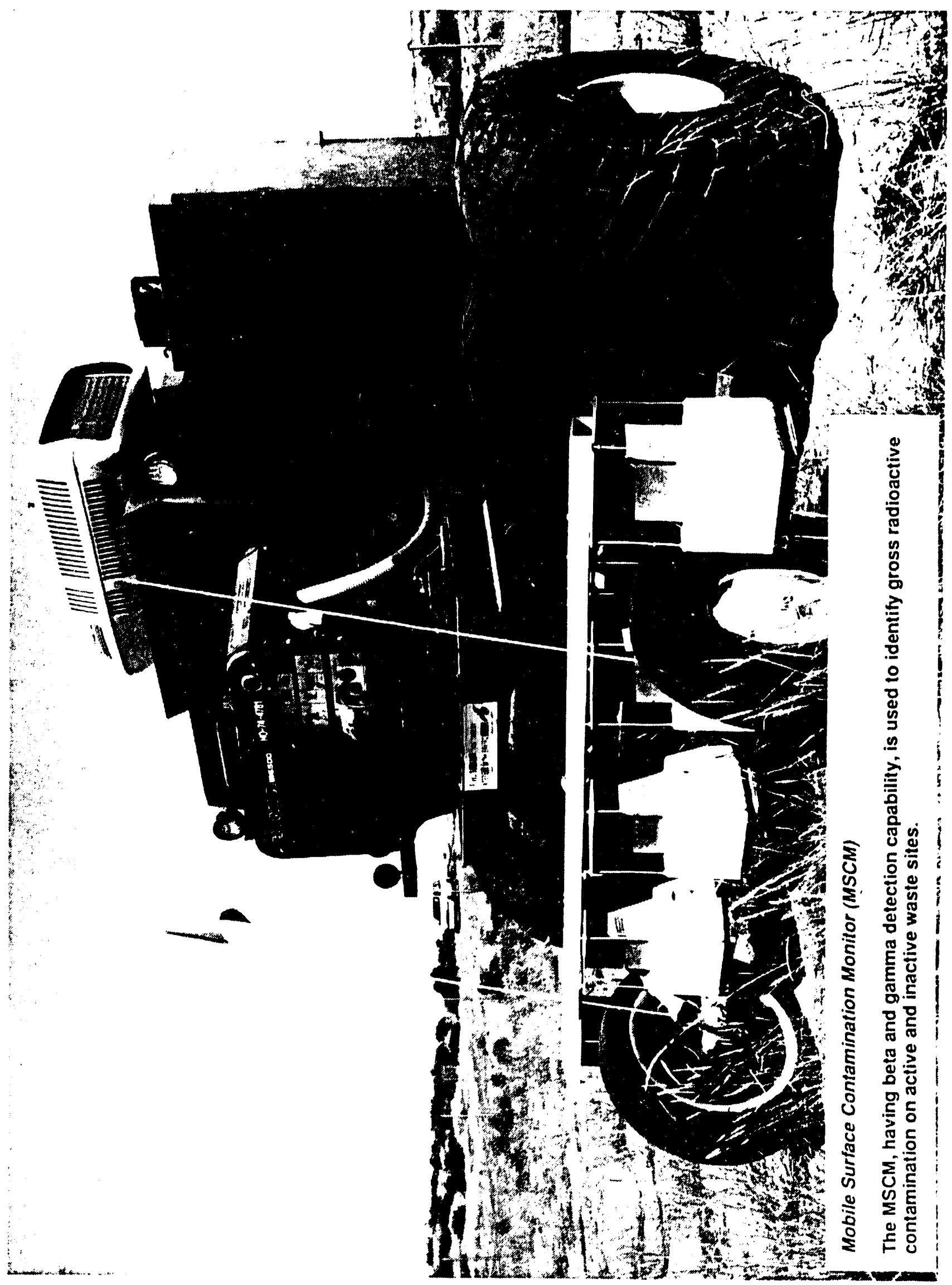




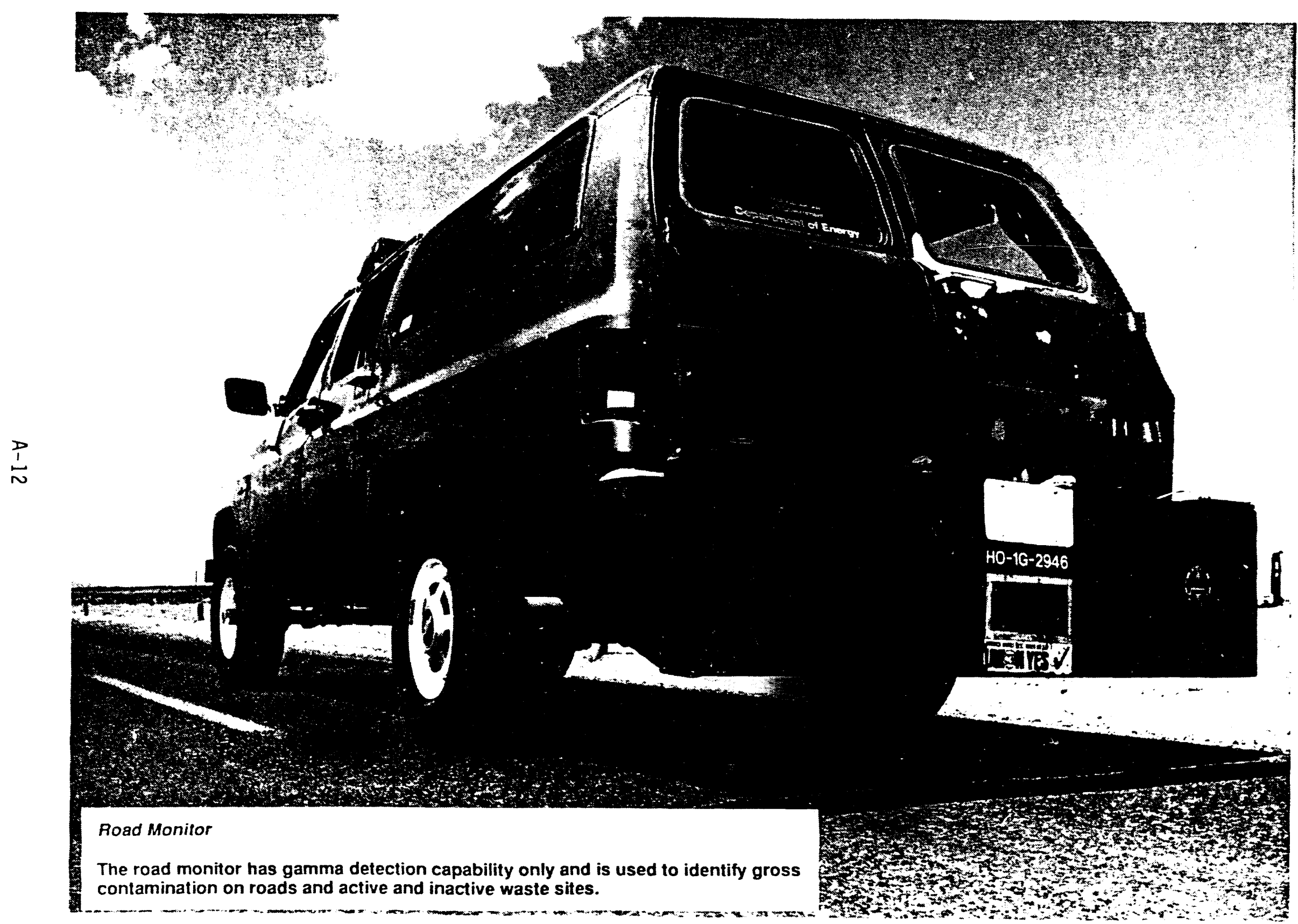




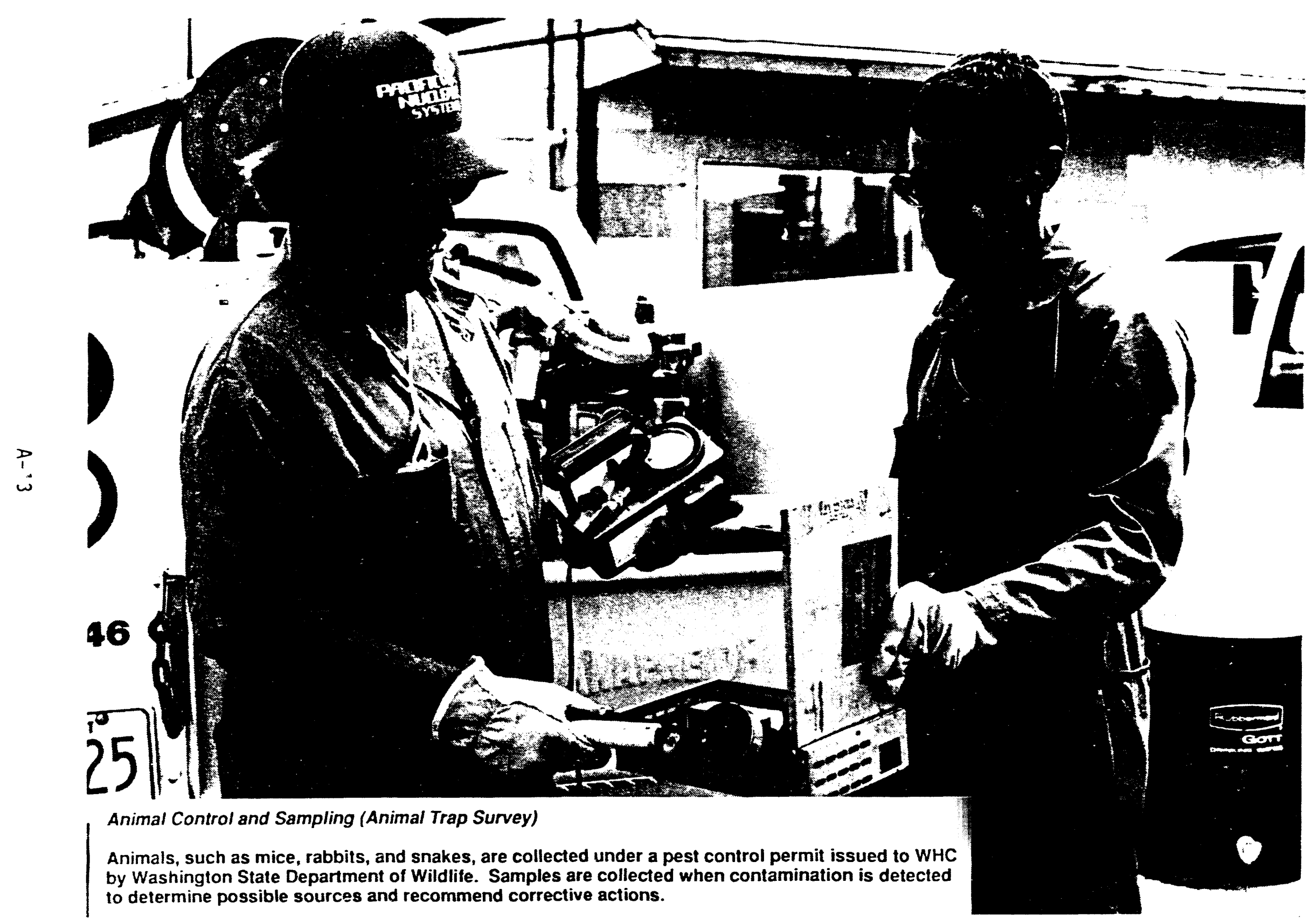

종
1
m
1
0
o
d 


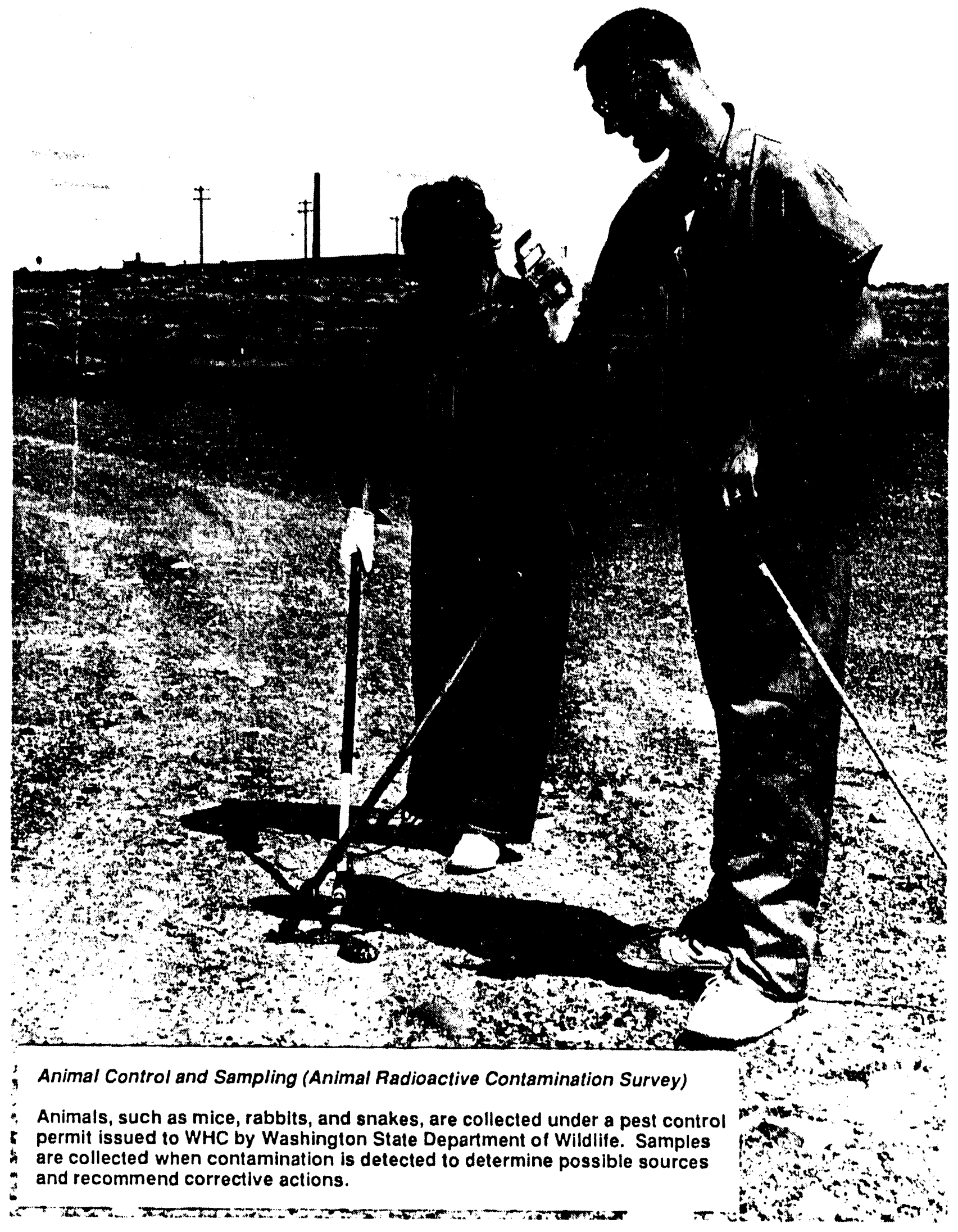




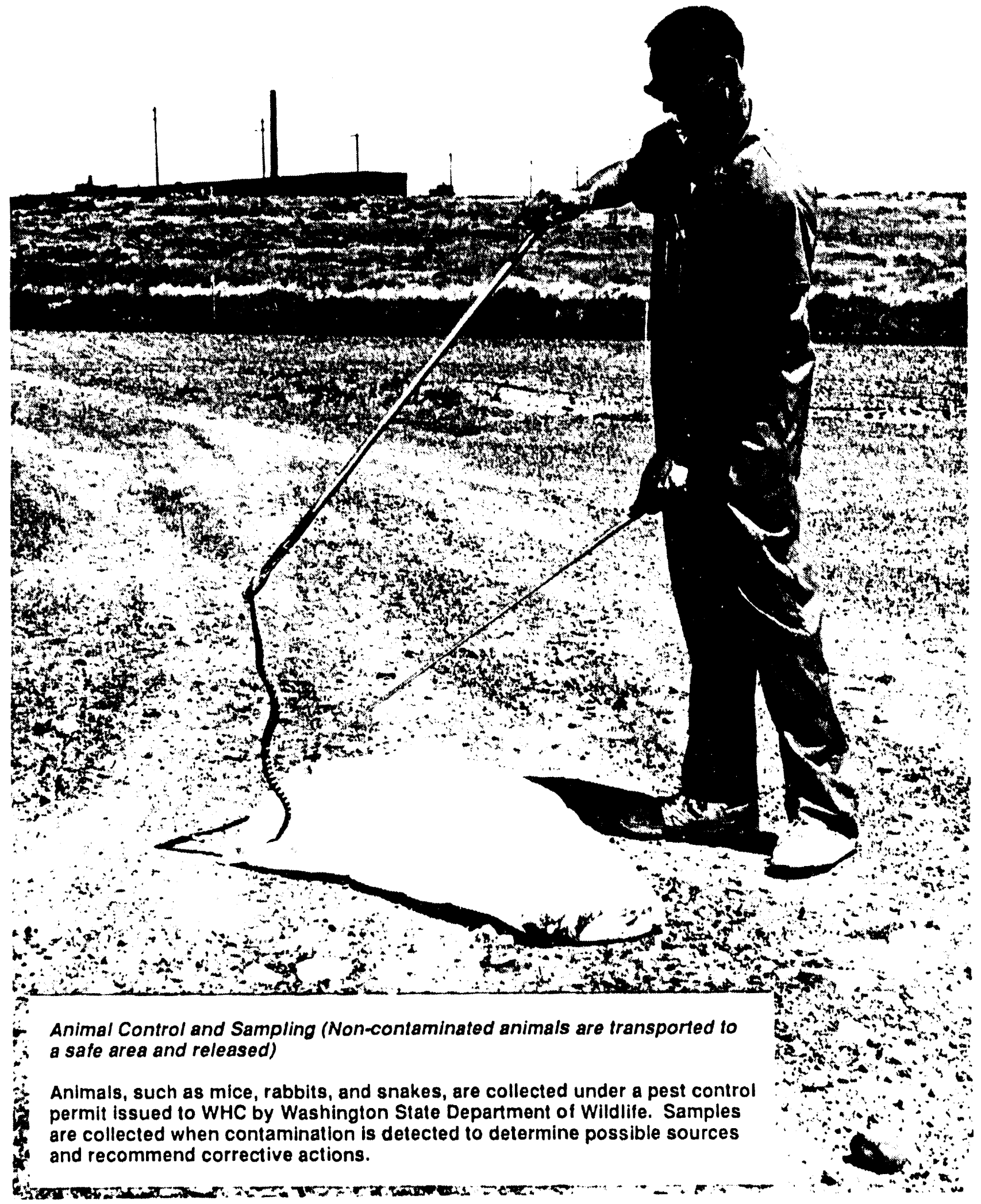




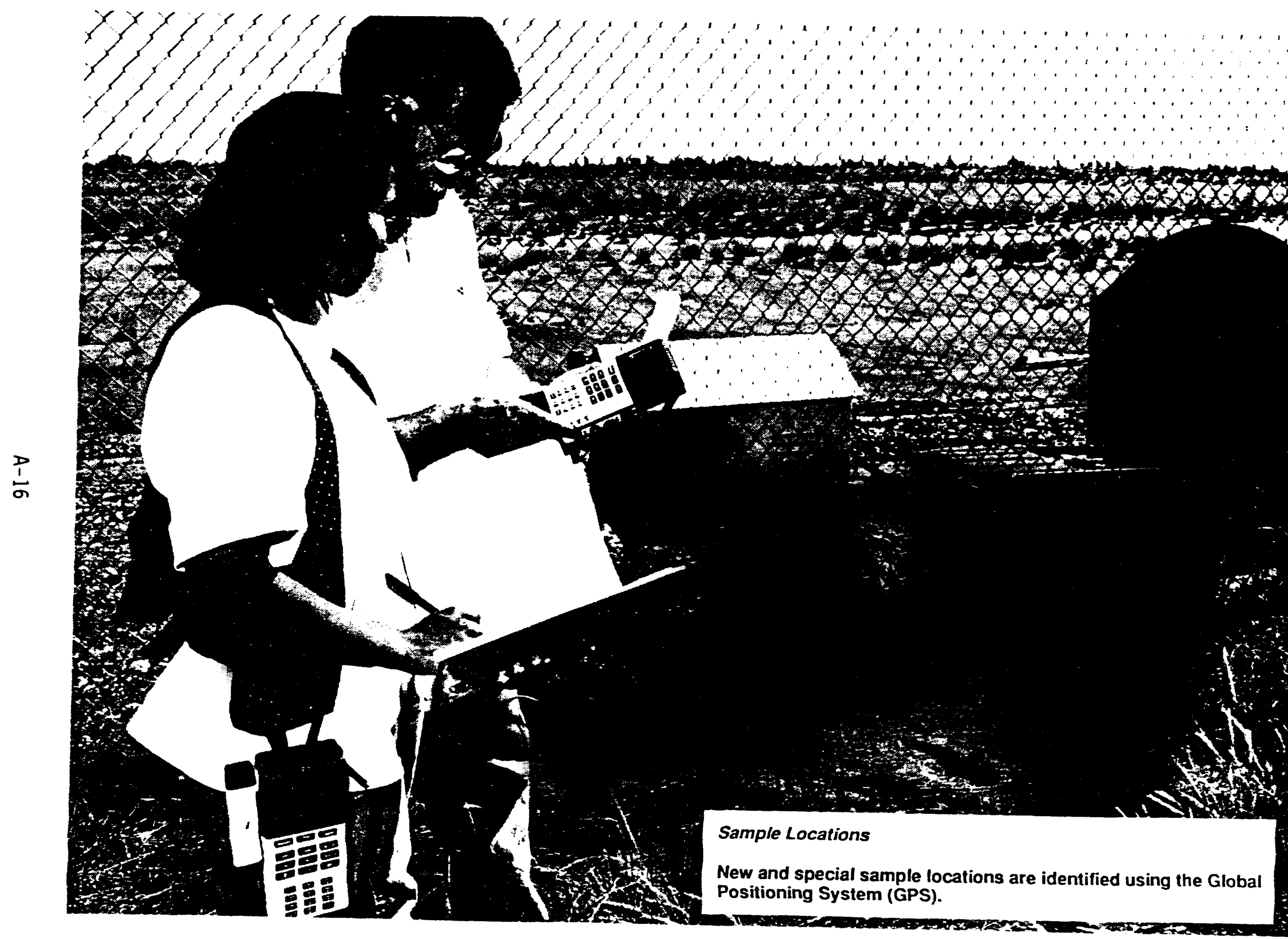


WHC-EP-0678

\section{DISTRIBUTION}

\section{Number of Copies}

Onsite

4

U.S. Department of Energy. Richland Operations Office
R. F. Brich
A5-55
M. J. Furman
R3-80
J. B. Hall
A5-55
R. A. Holten
A5-55

Pacific Northwest Laboratory

R. K. Woodruff (2)

K6-61

66

West inghouse Hanford Company

L. P. Diediker (10)

T1-30

J. J. Dorian

H6-30

D. S. Gunnink

$\mathrm{T} 1-25$

D. B. Jensen

H6-30

A. R. Johnson

H6-30

S. M. Mckinney

$\mathrm{T} 1-30$

P. C. Miller

N2-04

D. L. Mitchell

$\mathrm{H} 6-32$

C. J. Perkins

$\mathrm{X} 0-21$

J. A. Seamans

N2-04

J. W. Schmidt (40)

R. R. Thompson

H6-30

D. J. Watson

$\mathrm{H} 6-32$

Document Clearance

Administration (3)

X0-41

Central Files

EDMC

H4-17

L8-04

H6-08 


$$
\begin{aligned}
& \text { F } \\
& \text { : } \\
& \text { 胥 } \\
& \text { 蛋 } \\
& \text { 옴 } \\
& \xi \\
& \stackrel{D}{?} \\
& \text { 号 }
\end{aligned}
$$



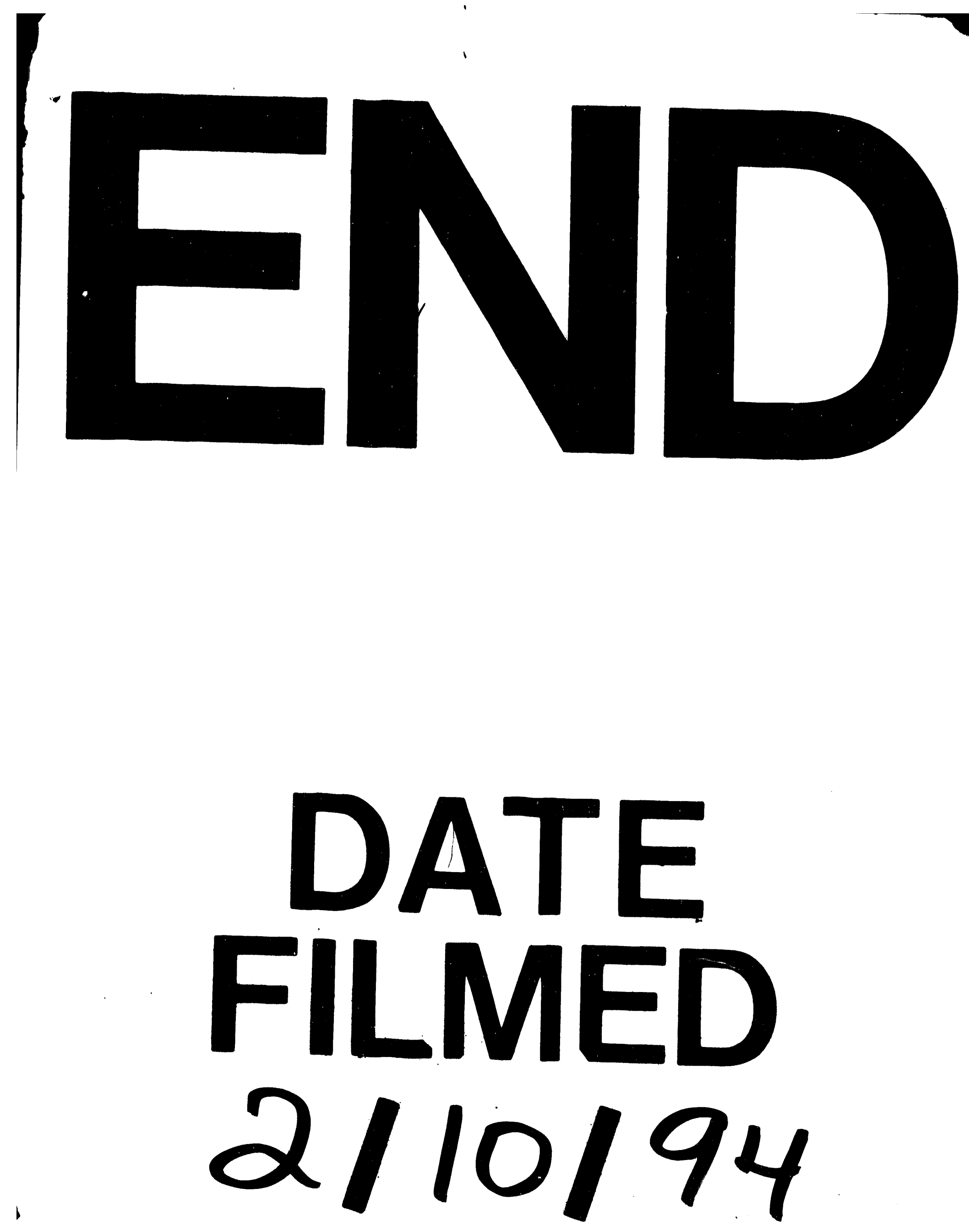
